\title{
Recent advances in the treatment of Clostridioides difficile infection: the ever-changing guidelines
}

\author{
Shruti Khurana ${ }^{1}$ Alyssa Kahl ${ }^{2}$ Kevin Yu ${ }^{3}$ Andrew W. DuPont ${ }^{4 *}$ \\ ${ }^{1}$ Department of Internal Medicine and Pediatrics, The University of Texas Health Science Center at Houston, Houston, TX, USA \\ ${ }^{2}$ Department of Internal Medicine, Baylor College of Medicine, Houston, TX, USA \\ ${ }^{3}$ Department of Internal Medicine, The University of Texas Health Science Center at Houston, Houston, TX, USA \\ ${ }^{4}$ Associate Professor, Department of Gastroenterology, Hepatology and Nutrition, The University of Texas Health Science Center at Houston, Houston, TX, USA
}

\begin{abstract}
Clostridioides difficile infection (CDI), formerly known as Clostridium difficile, continues to be the most common healthcareassociated infection worldwide. With the shifting epidemiology towards higher a incidence of community-acquired CDI and the continued burden on the healthcare system posed by high rates of CDI recurrence, there has been an impetus to advance the diagnostic testing and treatment strategies. Recent advancements over the past decade have led to rapidly changing guidelines issued by the Infectious Diseases Society of America and European Society of Clinical Microbiology and Infectious Diseases. With our comprehensive review, we aim to summarize the latest advances in diagnosing and treating CDI and thus attempt to help readers guide best practices for patient care. This article also focusses on cost-effectiveness of various therapies currently available on the market and provides an analysis of the current evidence on a relatively new monoclonal antibody therapy, Bezlotoxumab, to treat recurrent CDI.
\end{abstract}

\section{Keywords}

Clostridium Difficile Infection, IDSA, Fecal Microbiota Transplantation, CDI

\section{Peer Review}

The peer reviewers who approve this article are:

1. Nicola Petrosillo, Clinical and Research Department for Infectious Diseases, National Institute for Infectious Diseases L. Spallanzani, Via Portuense 292, 00149 Rome, Italy

Competing interests: No competing interests were disclosed.

2. Tanya Monaghan, Nottingham Digestive Diseases Centre, NIHR Nottingham Digestive Diseases Biomedical Research Unit, School of Medicine, University of Nottingham, Nottingham, UK

Competing interests: No competing interests were disclosed. 
*Corresponding author: Andrew W. DuPont (Andrew.DuPont@uth.tmc.edu)

Competing interests: The authors declare that they have no competing interests.

Grant information: The authors declared that no grants were involved in supporting this work.

Copyright: (C) 2020 DuPont AW et al. This is an open access article distributed under the terms of the Creative Commons Attribution License, which permits unrestricted use, distribution, and reproduction in any medium, provided the original work is properly cited.

How to cite this article: Khurana S, Kahl A, Yu K and DuPont AW. Recent advances in the treatment of Clostridioides difficile infection: the ever-changing guidelines. Faculty Reviews 2020 9:(13) https://doi.org/10.12703/b/9-13

Published: 18 Nov 2020, Faculty Reviews 9:(13) https://doi.org/10.12703/b/9-13 


\section{Introduction}

Clostridioides difficile infection (CDI), formerly known as Clostridium difficile, is the most common healthcare-associated infection worldwide. In the year 2011, CDI was responsible for almost half a million infections and caused approximately 29,000 deaths in the United States alone ${ }^{1}$. Hospital-acquired CDI (HA-CDI) cases lead to increased length of stay and result in a significant financial burden on the healthcare system ${ }^{2}$. In 2015, the total annual CDI-attributable cost in the United States was estimated to be about 6 billion $\mathrm{USD}^{2}$. Outcomes for a patient infected with $C$. difficile range from asymptomatic colonization to severe diarrhea, which can progress to toxic megacolon, bowel perforation, septic shock, and even death. However, the incidence of CDI is decreasing globally. This has been attributed to the rapidly decreasing prevalence of the hypervirulent BI/NAP1/027 strain, which led to major outbreaks across North America during the mid-2000s ${ }^{1,3-6}$. Increased antibiotic stewardship programs in hospitals have also significantly reduced the incidence and colonization of $\mathrm{CD}$ during recent years ${ }^{7}$.

With the introduction of more-sensitive $C$. difficile assays such as nucleic acid amplification tests (NAATs), more cases of CDI are being detected; however, not all of these cases result in clinically significant CDI that requires treatment ${ }^{8}$. Communityacquired CDI (CA-CDI) has also gained much attention in the past decade ${ }^{5,9,10}$. It is estimated that almost $40 \%$ of all CDI cases are community associated ${ }^{9}$. CA-CDI affects younger populations and those without antibiotic exposures who were traditionally thought to be at lower risk for CDI infections ${ }^{3,9}$. Moreover, in the era of molecular testing, several other toxigenic strains have been identified from animal sources and the environment with varying antibiotic susceptibility in different parts of the world, most notably ribotypes 078 and $244^{11-13}$. The shifting epidemiology of CDI concerns regarding overdiagnosis and over-treatment, and rising costs of the United States healthcare system have created an impetus for continued research in the detection and treatment of clinically significant CDI.

With the recent changes in the guidelines for the management of CDI, we aim to summarize the latest advances in the field of diagnosis and treatment of CDI and thus help readers guide patient care.

\section{Risk factors}

C. difficile causes alteration of the intestinal microbiota that allows spores of $C$. difficile to proliferate in the gut mucosa. Symptomatic infection is thought to be due to the production of toxins A and B that leads to the impairment of epithelial barrier function through disruption of cell-cell tight junctions ${ }^{14}$. Current or recent (within 8 weeks) use of antibiotics is one of the most important risk factors in $\mathrm{CDI}^{1,2,9}$. Antibiotics like clindamycin, third-generation cephalosporins, amoxicillin, and fluoroquinolones have been implicated in increasing the risk of developing $\mathrm{CDI}^{15}$. Antibiotic use increases the risk by at least 8 - to 10 -fold in the first month and 3 -fold in the subsequent
2 months $^{9}$. Thibault et al. demonstrated that the risk of development of CDI is directly proportional to the number of antibiotics used and the duration of antibiotic exposure ${ }^{16}$. In a recent study by Hung et al., the incidence of CDI was two times higher after 7-11 days of cephalosporin exposure ${ }^{17}$. Other risk factors that predispose patients to CDI include age $\geq 65$ years, exposure to healthcare facilities including outpatient clinics, hospital admissions, and long-term stays in nursing homes. Recent gastrointestinal surgery, especially colonic resection, immunocompromised states (e.g. malignancy, diabetes mellitus, and HIV), exposure to antineoplastic agents, gastric acid suppressants (e.g. proton pump inhibitors [PPIs]), and co-morbidities like inflammatory bowel disease (IBD) and chronic or endstage renal disease have also been implicated in $\mathrm{CDI}^{15,17-22}$. Patients on PPIs have a $65-75 \%$ higher incidence of developing CDI than the normal population, as shown by two large metaanalyses $^{23,24}$. Although an association between PPI use and CDI has been established, it has not been proven that PPI use increases the risk of CDI, as $C$. difficile spores are resistant to gastric acid. It is possible that more colonized patients on PPIs are being tested for CDI because of the well-known side effect of diarrhea.

\section{Update in diagnosis}

With the development of highly sensitive diagnostic testing, many efforts have been made to stratify patients with suspected CDI to avoid overuse of resources and inappropriate treatment of asymptomatic carriers/colonizers. Alasmari et al. reported that approximately $15 \%$ of patients were colonized with toxigenic C. difficile spp. at the time of admission ${ }^{25}$. Kwon et al. showed that careful selection of patients based on clinical presentation of unexplained watery diarrhea (Bristol stool scale 6-7; at least three loose to watery bowel movements in a 24-hour period), associated with abdominal pain or cramping, and objective data can substantially increase the positive predictive value of the tests ${ }^{26}$. The first step should always be a comprehensive historical evaluation to rule out other etiologies of diarrhea, including laxative use in the previous 48 hours of symptom onset, administration of chemotherapeutic agents, enteral feeding, intra-abdominal surgical intervention, and co-morbidities like IBD, irritable bowel syndrome, and other non-infectious causes, etc. ${ }^{26-28}$. According to Dubberke et al., recent use of laxatives was noted in one in five patients being tested for CDI in the hospital ${ }^{27,28}$. A highly effective method that can be implemented by laboratories is accepting only diarrheal stool samples and rejecting formed stool specimens.

Imaging of patients with suspected CDI is not recommended owing to poor sensitivity as a diagnostic test, with normal computed tomography (CT) reports in approximately $39 \%$ of cases $^{29}$. However, patients with a complicated clinical picture who have findings such as colon wall thickening or "mucosal thumbprinting" on abdominal CT are indicative of CDI with a high positive predictive value for infection and should be considered for treatment ${ }^{29}$. Lower endoscopic studies like flexible sigmoidoscopy are generally not recommended but can be useful in the settings of a coexisting colonic pathology, 
inconclusive lab tests, colonic ileus where stool sample is not available, or acute worsening symptoms when rapid diagnosis is important to determine the need for urgent surgical intervention $^{30}$. The classic "pseudomembranous colitis" has been reported in about half of CDI cases undergoing endoscopy, thus limiting its use as a test of choice for the confirmation of $\mathrm{CDI}^{30}$.

Current diagnostic assays include toxigenic culture (TC), cell culture cytotoxicity neutralization assay (CCCNA), enzyme immune assays (EIAs) for toxin A and toxin B, NAATs, and glutamate dehydrogenase $(\mathrm{GDH})$ tests. Table 1 depicts the estimated relative cost, turn-around time, and sensitivity and specificity of each of these tests.

TC and CCCNA have been considered reference tests for many decades. TC involves inoculation of a stool sample to an anaerobic medium for 2 days up to a week, followed by identification of colonies by Gram stain, colony morphology, and advanced biochemical testing to determine the presence of C. difficile. This is labor intensive and cumbersome and has a long incubation period, which reserves its use as a test for laboratory comparison and epidemiological studies instead of routine diagnostic testing. In CCCNA, a stool filtrate is applied over an appropriate cell line to look for toxin cytopathic effect, followed by confirmation with toxin neutralization assay. The disadvantages include variable sensitivity, lack of standardization at testing sites, expertise required for handling and maintenance of stool samples, and subjective variability in the interpretation of results.

There are many commercially available EIA kits that use monoclonal or polyclonal antibodies against toxins $\mathrm{A}$ and $\mathrm{B}$ produced by $C$. difficile. It is a quick and inexpensive test but comes with several drawbacks, including poor sensitivity, high rates of false positives, and inter-laboratory variations. GDH is an enzyme produced by all strains of $C$. difficile. GDH tests are rapid and economical with a very high sensitivity of over $90 \%$. Since this enzyme is produced by both toxigenic and non-toxigenic strains of $C$. difficile, these tests have a very low specificity and should be used only as a screening assay. This was supported by a recent pre- and post-implementation study performed by Vogelzang et al. The authors showed that owing to a high negative predictive value of $98.8 \%$, using GDH as a screening tool followed by testing positive samples with EIA for toxin and later on with NAAT significantly reduced the patient isolation time as opposed to using NAAT alone ( 28 hours vs. 50.8 hours; $P<0.001)^{31}$.

There are inconclusive data regarding the utility of EIA in clinical practice. In 2013, Planche et al. reported that EIA A/B-positive cases have worse clinical outcome than TC-positive but stool toxin-negative $\operatorname{cases}^{32}$. Around the same time, Humphries et al. conducted a study with NAAT and EIA with TC as standard reference to determine the correlation of EIA positivity with disease severity. NAAT was positive in $98 \%$ of samples, while $49 \%$ and $58 \%$ of patients tested EIA positive in mild and severe CDI, respectively. This concluded that there is no significant difference in clinical symptoms and severity in stool toxin-positive cases $^{33,34}$.

NAAT became commercially available in the late 2000s. The commercially available assays detect genes that code for toxins $\mathrm{A}$ and $\mathrm{B}, t c d A$ and $t c d B$, respectively, and binary toxin gene, $c d t$. These assays are fast and are more than $90 \%$ sensitive and specific in comparison to $\mathrm{TC}^{35}$. Apart from the steep cost difference compared to EIAs and GDH tests and low positive predictive value, there are some concerns with the clinical interpretation of positive tests in asymptomatic colonizers, and a notable increase in the incidence of CDI has been seen since the implementation of NAATs in healthcare facilities ${ }^{27}$.

The concept of combination testing or multistep algorithm was a major highlight of the newly revised guidelines published by the Infectious Diseases Society of America (IDSA) and Society for Healthcare Epidemiology of America (SHEA) ${ }^{5}$. The multistep algorithm comprises combination testing with GDH test plus EIA, NAAT plus EIA, or GDH test plus EIA arbitrated by NAAT in pre-defined criteria for testing stool samples. This two-step algorithm was also supported by the European Society

Table 1. Properties of Clostridioides difficile diagnostic stool studies.

\begin{tabular}{|l|l|l|l|l|l|}
\hline Assay & Utilization & $\begin{array}{l}\text { Cost per } \\
\text { specimen }^{36}\end{array}$ & $\begin{array}{l}\text { Turnaround } \\
\text { time }\end{array}$ & $\begin{array}{l}\text { Sensitivity } \\
(\%)\end{array}$ & $\begin{array}{l}\text { Specificity } \\
(\%)\end{array}$ \\
\hline GDH test & $\begin{array}{l}\text { Detects enzymatic } \\
\text { product of antigen }\end{array}$ & $\$$ & $<4$ hours & $>90$ & 80 \\
\hline NAAT & $\begin{array}{l}\text { Detects genes } \\
\text { encoding for toxins }\end{array}$ & $\$ \$ \$$ & $\begin{array}{l}30 \text { minutes } \\
\text { to } 2 \text { hours }\end{array}$ & $90-100$ & $90-100$ \\
\hline EIA & $\begin{array}{l}\text { Detects free toxin } \\
\text { Detects toxigenic }\end{array}$ & $\$$ & 1 hour & $40-100$ & $90-95$ \\
\hline TC & $\begin{array}{l}\text { Deters } \\
\text { spores/organism }\end{array}$ & $\begin{array}{l}48 \text { hours to } \\
7 \text { days }\end{array}$ & $>90-100$ & $>90$ \\
\hline CCCNA & $\begin{array}{l}\text { Detects free toxin and } \\
\text { its effects on cells }\end{array}$ & $\$ \$$ & $24-48$ hours & $65-85$ & $>90$ \\
\hline
\end{tabular}

CCCNA, cell culture cytotoxicity neutralization assay; EIA, enzyme immune assay; GDH, glutamate dehydrogenase; NAAT, nucleic acid amplification test; TC, toxigenic culture. 
of Clinical Microbiology and Infectious Diseases (ESCMID) and proposed using either GDH test or NAAT for screening followed by reflex testing of positive samples with EIA to confirm the Clostridioides present is toxigenic ${ }^{37}$. It has been shown by multiple authors that stool samples that are found to be positive by NAAT followed by a multi-step toxin test have a higher chance of detecting cases of clinically significant disease and are associated with a higher risk of developing CDI-related complications (megacolon, need for colectomy, admission to intensive care unit, 30-day all-cause mortality, duration of diarrhea, readmission, and recurrence) as opposed to only NAAT positive cases ${ }^{38,39}$.

Ignatius et al. performed a study to assess the validity of ESCMID guidelines in testing patients for CDI in the outpatient setting. Of the 9,802 stool samples studied, approximately 90\% concordance was noted between GDH and EIA testing (95\% confidence interval [CI] 89.2-90.4\%). However, of the discordant GDH+/EIA - samples, $68 \%$ were positive by NAAT (95\% CI 64.7-71.0\%), and of the discordant GDH-/EIA+ samples, $85 \%$ were negative by NAAT $(95 \% \text { CI } 71.2-93.5 \%)^{40}$. It is generally accepted that in facilities that use screening practices (e.g. rule out laxative use), the NAAT can be used as a stand-alone test without confirmatory EIA for toxin.

Fecal biomarkers like fecal calprotectin and lactoferrin have been assessed to determine a correlation of severity of CDI and recurrence risk $^{41}$. These are non-specific markers of inflammation with no concrete data for their utility in the diagnosis or management of $\mathrm{CDI}^{42-44}$.

Repeat testing within 7 days of initial test (regardless of the result) or as test-of-cure are not recommended because of a high risk of false-positive results, very low diagnostic yield, and chance of unnecessary prolonged treatment, as more than $60 \%$ of patients may have positive results even after treatment because of asymptomatic spore shedding for up to 6 weeks ${ }^{45,46}$.

\section{Classification}

There are several classifications of CDI based on disease severity and epidemiology. The IDSA/SHEA classifies CDI into healthcare-associated (onset of disease on or after the fourth day of admission to a healthcare facility), community-onset healthcare-associated (onset of disease within 4 weeks of discharge from the healthcare facility), and community-associated (sporadic CDI or onset at least 4 weeks after hospital discharge) disease $^{5}$. This sheds light on the continued risk of CDI in patients after discharge due to suppressed immunity and prolonged antibiotic course post-hospitalization.

Despite this proposed classification, the management of CDI is most commonly described based on severity and number of episodes. There are many factors that have been studied to predict treatment response or failure, risk of recurrence, and degree of severity. There is no criterion that has been validated to assess the severity of CDI at presentation; however, the presence of fever $\left(>38.5^{\circ} \mathrm{C}\right)$, white blood cell $(\mathrm{WBC})$ count $>15 \times 10^{9} / \mathrm{L}$, and creatinine $>1.5 \mathrm{mg} / \mathrm{dL}$ have been associated with severe and complicated $\mathrm{CDI}^{5}$.

\section{Updates in treatment}

The goal of treatment is the resolution of diarrhea and prevention of recurrence, thus decreasing the disease burden. Minimizing unnecessary antibiotic exposure and prompt discontinuation of inciting antibiotic agent(s), if possible, play a pivotal role in the management of CDI. Antibiotic stewardship programs and infection control measures (e.g. hand hygiene) are proven to be the most cost-effective methods in significantly reducing the incidence of CDI and its recurrence ${ }^{7}$. Supportive measures like rehydration and correction of electrolyte imbalances should be addressed in all patients diagnosed with CDI.

Empiric treatment is considered inappropriate in suspected CDI cases, with the exception of fulminant CDI and in cases where substantial delay is expected in retrieving diagnostic studies. The rationale is to limit the overuse of antibiotics and prevent the overgrowth of multidrug-resistant pathogens ${ }^{47}$. Empiric therapy also increases the risk of false-negative PCR results on pre-treated stool samples. Sunkesula et al. demonstrated that a positive PCR for CDI is converted to negative after 1,2 , and 3 days of treatment ${ }^{48}$. Anti-motility agents like loperamide are generally contra-indicated because of an increased risk of colonic dilation, perforation, and higher mortality ${ }^{49}$.

\section{Initial CDI}

Initial CDI is defined as onset of symptoms with positive diagnostic test and no history of CDI within the previous 8 weeks. Metronidazole had long been the recommended initial treatment of CDI. However, the most recent IDSA/SHEA guidelines published in 2018 replaced metronidazole with oral vancomycin (125 mg given by mouth four times a day for 10 days) or fidaxomicin (200 mg given by mouth twice daily for 10 days) as the first line of treatment ${ }^{5}$. This was a major revelation supported by strong clinical evidence. There are many reasons for metronidazole being replaced as the first line of treatment for initial CDI, including inferiority of metronidazole to vancomycin in achieving clinical cure rates, higher recurrence rates in the first 30 days post-treatment, delayed response to treatment, need for longer antibiotic course of up to 14 days, and concern for neurotoxicity with repeated and prolonged use $^{50-53}$. Despite the higher cost of vancomycin and fidaxomicin compared to metronidazole, the overall cost of repeated hospitalizations and treatment is expected to be lower with initial treatment with vancomycin or fidaxomicin ${ }^{54,55}$.

Fidaxomicin gained impetus as the standard of care for initial episodes of CDI after two randomized, double-blind phase III trials demonstrated non-inferiority of fidaxomicin to vancomycin, with sustained clinical cure rates ranging from 88 to $92 \%$ and lower recurrence rates ${ }^{56,57}$. Lower recurrence rates may partly be the result of the narrower activity and specificity for Clostridioides of fidaxomicin compared to vancomycin. 
Other alternative therapies currently being evaluated include nitazoxanide, fusidic acid, rifaximin, rifampin, bacitracin, tigecycline, teicoplanin, cadazolid, surotomycin, ridinilazole, LFF571, ramoplanin, CRS3123, auranofin, NVB302, thuricin CD, lacticin 3147 , and acyldepsipeptide antimicrobials ${ }^{58-67}$. With most drugs in their initial phases of trials, there is a lack of strong clinical evidence of superiority for any of the above antimicrobials when compared to vancomycin and fidaxomicin.

\section{Recurrent CDI}

One of the major hurdles in the management of CDI is recurrence, which is defined as repeat onset of symptoms with positive diagnostic testing within $2-8$ weeks of first CDI episode. It is estimated that approximately a quarter of patients will suffer at least one additional episode, especially when treated with metronidazole or vancomycin ${ }^{68}$. This population is also shown to suffer from $33 \%$ higher mortality compared to those with only one episode of $\mathrm{CDI}^{69}$. The subsequent CDI can be from the previously treated strain (relapse) or from a new strain due to persistent risk factors (re-infection). Whole genome sequencing showed that $75-85 \%$ of recurrences are associated with same-strain relapses ${ }^{70}$. Regardless of the strain, the treatment is similar for both causes. Major risk factors associated with recurrence include age $\geq 65$ years, continued use of antibiotics, severe initial bout of CDI, and possibly gastric acid suppression (Table 2) ) $^{71,72}$.

The treatment of first recurrence should be by either of the following two regimens: vancomycin in tapered and pulse doses (125 mg four times per day for the first 10 days, followed by $125 \mathrm{mg}$ two times per day for a week, $125 \mathrm{mg}$ once per day for a week, and then $125 \mathrm{mg}$ every 2 or 3 days for 2-8 weeks) or fidaxomicin if vancomycin was used initially. Several studies have shown that pulse and tapered vancomycin has cure rates close to $74 \%$ in recurrent CDI (rCDI), especially if standard 10-day vancomycin course or metronidazole was used for the treatment of the previous $\mathrm{CDI}^{73}$. The hypothesis of prolonged vancomycin therapy is to eradicate the vegetative spores that were dormant during the 10-day treatment course. On the other hand, the use of fidaxomicin for the initial CDI episode has been associated with lower initial recurrence rate but has not been shown to decrease subsequent recurrences ${ }^{74}$.

Table 2. List of risk factors for recurrent Clostridioides difficile infection.

- Age $\geq 65$ years

- Immunocompromised states (diabetes mellitus, HIV)

- Gastric acid suppressants (PPIs and H2 blockers)

- Hypervirulent strains of $C$. difficile (ribotype 027, 078, or 244)

- Inflammatory bowel disease

- Recent gastrointestinal surgery (partial colectomy)

- Previous C. difficile infection(s)

- Chronic/end-stage renal disease

- Antibiotic use - current or within the past 3 months

HIV, human immunodeficiency virus; PPIs, proton pump inhibitors
In a phase III randomized controlled trial performed by Cornely et al. to compare fidaxomicin and vancomycin for rCDI (first episode), similar cure rates were noted for both drugs $(>90 \%)$, but there was a significantly lower rate of second recurrence of CDI in the fidaxomicin arm (35.5\% vs. $19.7 \%$, $P=0.045)^{75}$. Despite common clinical practice, continued prophylactic treatment with agents like rifaximin has not been proven to be effective in preventing recurrence in high-risk groups $^{76}$.

\section{Role of fecal microbiota transplantation}

Fecal microbiota transplantation (FMT) is a rapidly emerging therapy that has gained popularity in the past few decades with promising active research. The fundamental concept behind FMT is the delivery of a more physiologic fecal microbiome from a healthy stool donor into the gut of a patient to correct the underlying severe intestinal dysbiosis. Since its first description dating back to the 1980 s, multiple systematic reviews and randomized controlled trials have demonstrated the efficacy and safety of FMT for patients who have rCDI. In these patients, FMT was shown to be superior to standard antibiotic therapy with higher clinical cure rates and lower recurrence rates ${ }^{77-79}$. Furthermore, FMT administered after a course of vancomycin is superior to vancomycin alone for $\mathrm{rCDI}^{78,79}$. As per the current IDSA/SHEA guidelines, FMT is recommended for patients with multiple recurrences of CDI who have failed appropriate antibiotic treatments ${ }^{5}$.

Several routes of stool delivery have been explored, including delivery via feeding tube, infusion by colonoscopy, enemas, and oral capsules with lyophilized stool. All methods have been shown to have excellent safety profiles and similar cure rates between 82 and $95 \%$ after one or two transplants in most studies $^{80}$. Most clinicians, depending on institutional policies, give a brief antibiotic course to FMT recipients prior to the procedure with the intention of decreasing the disease burden.

FMT is well tolerated by patients and has minimal short-term direct adverse effects. Most of the adverse events are related to complications secondary to the procedures for the instillation of the stool including colonic microperforation, gastrointestinal bleeding, and peritonitis. Adverse events related to FMT itself are usually minor, are self-limited, and usually resolve within a few hours. These include abdominal pain, bloating, diarrhea, constipation, and fever ${ }^{81}$.

Phase III clinical trials are currently underway to further investigate the efficacy and feasibility of using FMT as a primary therapy for CDI. A small initial proof-of-concept trial out of Norway showed potential superiority of FMT over traditional antibiotic therapies ${ }^{82}$. Recurrent CDI is a major concern in IBD patients. Unfortunately, the success of FMT has been variable in this group along with the risk of worsening flares, as reported by some authors ${ }^{83-85}$.

One of the challenges with FMT is the lack of standardized protocols for stool screening and selection, as well as standardized donor sources. Careful selection of a healthy donor is a 
critical step, and strict exclusionary criteria should be applied by centers to prevent iatrogenic transmission of infectious diseases, which now include COVID-19 ${ }^{81}$. In 2019, DeFilipp et al. reported one such notable case series of two patients acquiring extended-spectrum beta-lactamase Escherichia coli bacteremia post-FMT, resulting in the death of one of these patients ${ }^{86}$.

One small observational study of 32 patients looked at establishing stool banks by reconstituting stool samples from single donors with clinical cure rates on par with other FMT studies using heterogenous stool donations ${ }^{87}$. Other studies have explored the logistical barriers as well. The potential use of freeze-thawed stool samples versus fresh feces has shown non-inferiority between the two types of preparations that could potentially lead to the establishment of stool banking for storage and later use ${ }^{88,89}$.

The potential long-term effects of the alteration of a host's gut microbiota through FMT are unknown. Given the diverse nature of stool donor sources, there may be species of bacteria that are currently of unknown significance and unculturable bacteria that could result in unforeseen health consequences in the recipient. In a 2013 study of 77 patients by Brandt et al., in which the investigators followed the recipients of FMT over the course of 3 months, four of the 77 patients (5\%) had developed autoimmune or rheumatologic disorders ${ }^{90}$. It is unknown at this time whether the new autoimmune disorders were related to FMT. Further work needs to be conducted to determine the long-term safety profile of this treatment.

\section{Severe CDI}

Severe CDI can be differentiated from less-severe disease by the proposed criteria described before: presence of fever $\left(>38.5^{\circ} \mathrm{C}\right)$, WBC count $>15 \times 10^{9} / \mathrm{L}$, and creatinine $>1.5 \mathrm{mg} / \mathrm{dL}$. Initial treatment of severe CDI includes vancomycin $125 \mathrm{mg}$ orally four times daily for 10 days or fidaxomicin $200 \mathrm{mg}$ orally twice daily for 10 days $^{5}$. Patients with severe disease may also benefit from intravenous metronidazole, especially if there is delayed passage of oral antibiotics, as metronidazole is metabolized by the liver and excreted through the biliary system into the small intestine ${ }^{91,92}$. Mucosal disruption in severe disease can cause systemic absorption of vancomycin, and serum vancomycin levels should be monitored in patients with renal failure ${ }^{93}$. FMT has been proposed as first-line therapy for severe cases of CDI. A retrospective cohort study of 111 patients by Hocquart et al. found significant improvement in survival in severe CDI (odds ratio $0.08 ; P=0.001$ ) and suggests the need for further studies to support FMT as a first-line treatment ${ }^{94}$.

\section{Fulminant CDI}

Fulminant CDI is defined as an infection that is complicated by hypotension, shock, ileus, or megacolon. Early diagnosis and treatment are essential, as the disease can rapidly progress and has a high mortality rate close to $44 \%{ }^{95}$. Antibiotic therapy for fulminant CDI consists of enteric vancomycin $500 \mathrm{mg}$ (orally or via nasogastric tube) four times daily and parenteral metronidazole $500 \mathrm{mg}$ every 8 hours. In cases of ileus, rectal vancomycin may be administered via enema with caution for risk of colonic perforation $(500 \mathrm{mg}$ in $100 \mathrm{~mL}$ normal saline per rectum, retained for as long as possible and administered every 6 hours) $)^{5}$. Early surgical consultation is warranted for patients who show no improvement with medical therapy or have a rising serum lactate level $(\geq 2.2 \mathrm{mmol} / \mathrm{L})$ or rising $\mathrm{WBC}$ count $(\geq 20,000)^{96}$. Surgical intervention can be life-saving for select patients ${ }^{96-99}$. A systematic review of 1,433 patients undergoing emergency surgery for CDI found the strongest predictors of postoperative mortality to be preoperative intubation, acute renal failure, multiple organ failure, and shock requiring vasopressors $^{100}$. Total colectomy with end ileostomy was associated with the lowest rates of mortality and reoperation; however, less-extensive procedures can be considered for patients with earlier stage disease ${ }^{100}$.

\section{Role of bezlotoxumab}

Bezlotoxumab is a fully humanized monoclonal antibody that neutralizes $C$. difficile toxin $\mathrm{B}$. Two multicenter, phase III, placebo-controlled clinical trials (MODIFY I/MODIFY II) showed patients receiving bezlotoxumab had a significant reduction in the rate of rCDI after 12 weeks of infusion (17\% vs. $28 \%$ in MODIFY I, $P<0.001$, and $16 \%$ vs. $26 \%$ in MODIFY II, $P<0.001)^{101}$. Although the majority of the patients $(94 \%)$ received bezlotoxumab within 6 days of initiation of standard-of-care (SOC) antibiotics, there was no difference in rCDI from the timing of bezlotoxumab infusion ${ }^{102}$. In October 2016, the US Food and Drug Administration approved the use of bezlotoxumab as adjunctive therapy combined with standard treatment for CDI in patients with high risk of recurrence. This is administered intravenously during standard CDI treatment as a single infusion of $10 \mathrm{mg} / \mathrm{kg}$ over 60 minutes with no need for dose adjustments for renal or hepatic impairment. Though this treatment is well tolerated, infusion-related reactions (generally mild) were noted in $10 \%$ of patients. Serious drug-related adverse events $(0.5 \%)$ were related to infections and cardiac disorders in patients with known congestive heart failure. This led to caution on the use of bezlotoxumab in patients with heart failure $^{103}$. A post-hoc analysis proved that bezlotoxumab reduced rCDI, decreased the incidence of future FMTs, and promoted reduction in 30-day readmissions in patients with one or more risk factors for recurrence ${ }^{104}$. In an analysis looking at inpatient hospital stays for CDI, it was found that patients who were treated with bezlotoxumab had a decreased length of hospitalization ${ }^{105}$. A recent multicenter cohort study performed by Hengel et al. tested the efficacy of bezlotoxumab on 200 patients receiving SOC antibiotics. The authors noted a 90-day rCDI prevention rate of $84.1 \%$. The high success rate was noted with all SOC antibiotics and was independent of the time of diagnosis and the time of infusion ${ }^{106}$. In conclusion, bezlotoxumab is a very promising drug, and more head-to-head trials are needed to compare FMT and SOC with bezlotoxumab with regard to cost, efficacy, and safety.

\section{Cost-effectiveness of various therapies}

The management cost of CDI places a large burden on the healthcare system. Recurrent episodes of CDI make patients 12.5 times more likely to accrue inpatient hospital costs due to 
readmissions and longer hospital stays than patients without recurrence $^{107}$. Cost-effectiveness of therapy is a complex analysis which entails many direct and indirect aspects of resource utilization, including cost of diagnostic testing and medications, cost of hospitalization(s) including ICU care, and cost of contact isolation, readmissions, total length of stay, and management of complications and adverse events ${ }^{108}$.

There are three strategies to mitigate the total costs related to CDI: prevention of initial episode (infection control measures and antibiotic stewardship) $)^{109}$, cost-effective treatment of episode(s) with good cure rates, and prevention of recurrence(s). Among the available antimicrobials, metronidazole is the cheapest medication which is readily available in the resource-limited setting, but this is also the least-effective therapy which provided no gain in quality adjusted life years (QALY) ${ }^{110}$ and is no longer recommended as a first-line therapy when fidaxomicin or vancomycin is available. Despite the highest initial cost of fidaxomicin, some studies have found fidaxomicin to be more cost-effective than other treatment ${ }^{111}$; however, in a recent meta-analysis performed by Le et al. comparing treatment strategies for initial and rCDI, there were divergent results on the cost-effectiveness of fidaxomicin for initial and $\mathrm{rCDI}^{112}$. The findings are particularly conflicting for initial CDI of varying severity (mild-moderate and severe) ${ }^{113,114}$. On the other hand, FMT delivered by colonoscopy has been consistently shown to be the most cost-effective therapy for treating $\mathrm{rCDI}^{112,115-117}$.

\section{The role of probiotics in CDI}

There is extensive ongoing research to learn the potential role of probiotics in regulating gut dysbiosis, which in turn predisposes to the development of CDI. Traditionally, there has been limited evidence to support the effectiveness of probiotics in the prevention and treatment of CDI. In a recent metaanalysis, Shen et al. evaluated 19 randomized controlled trials that included 6,261 antibiotic-treated hospitalized patients who received Saccharomyces boulardii, Lactobacillus spp., Bifidobacterium spp., and Streptococcus spp., alone or in combination, with the aim of preventing the development of CDI. The study showed promising results, with a $>50 \%$ reduction in the rate of CDI in patients who received concurrent probiotics ${ }^{118}$. Future research will need to focus on elucidating the most-effective probiotic(s), optimum amount, and ideal duration for the prevention of CDI.

\section{Conclusion}

Antibiotic restriction is a vital measure to control CDI. All healthcare facilities should implement an antimicrobial stewardship program, which includes minimizing the frequency, duration, and number of antibiotic(s) whenever feasible. Vancomycin and fidaxomicin are both cost-effective treatments for an initial episode of CDI and preventing recurrence. FMT should strongly be considered in the treatment of rCDI after a second recurrence (third episode). The role of bezlotoxumab and other newer therapies is evolving and needs to be further studied.

\section{Abbreviations}

CA-CDI, community-acquired Clostridioides difficile infection; CCCNA, cell culture cytotoxicity neutralization assay; CDI, Clostridioides difficile infection; CI, confidence interval; CT, computed tomography; EIA, enzyme immune assay; ESCMID, European Society of Clinical Microbiology and Infectious Diseases; FMT, fecal microbiota transplantation; GDH, glutamate dehydrogenase; HA-CDI, hospital-acquired Clostridioides difficile infection; IBD, inflammatory bowel disease; IDSA, Infectious Diseases Society of America; NAAT, nucleic acid amplification test; rCDI, recurrent Clostridioides difficile infection; SHEA, Society for Healthcare Epidemiology of America; SOC, standard of care; TC, toxigenic culture; WBC, white blood cell

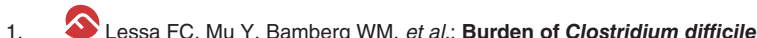
infection in the United States. N Engl J Med. 2015; 372(9): 825-34. PubMed Abstract | Publisher Full Text | Faculty Opinions Recommendation

2. Zhang S, Palazuelos-Munoz S, Balsells EM, et al:: Cost of hospital management of Clostridium difficile infection in United States-a meta-analysis and modelling study. BMC Infect Dis. 2016; 16(1): 447 PubMed Abstract | Publisher Full Text | Free Full Text

3. Wilcox MH, Shetty N, Fawley WN, et al:: Changing epidemiology of Clostridium difficile infection following the introduction of a national ribotyping-based surveillance scheme in England. Clin Infect Dis. 2012; 55(8): 1056-63. PubMed Abstract | Publisher Full Text

4. Avila MB, Avila NP, Dupont AW: Recent Advances in the Diagnosis and Treatment of Clostridium Difficile Infection [version 1; peer review: 3 approved]. F1000Res. 2016; 5: F1000 Faculty Rev-118. PubMed Abstract | Publisher Full Text | Free Full Text

5. McDonald LC, Gerding DN, Johnson S, et al.: Clinical Practice Guidelines for Clostridium difficile Infection in Adults and Children: 2017 Update by the
Infectious Diseases Society of America (IDSA) and Society for Healthcare Epidemiology of America (SHEA). Clin Infect Dis. 2018; 66(7): e1-e48. PubMed Abstract | Publisher Full Text | Free Full Text |

Faculty Opinions Recommendation

6. Oldfield EC IV, Oldfield EC III, Johnson DA: Clinical update for the diagnosis and treatment of Clostridium difficile infection. World J Gastrointest Pharmacol Ther. 2014; 5(1): 1-26.

PubMed Abstract | Publisher Full Text | Free Full Text

7. Baur D, Gladstone BP, Burkert F, et al.: Effect of antibiotic stewardship on the incidence of infection and colonisation with antibiotic-resistant bacteria and Clostridium difficile infection: a systematic review and meta-analysis. Lance Infect Dis. 2017; 17(9): 990-1001. PubMed Abstract | Publisher Full Text

8. Riggs MM, Sethi AK, Zabarsky TF, et al.: Asymptomatic carriers are a potential source for transmission of epidemic and nonepidemic Clostridium difficile strains among long-term care facility residents. Clin Infect Dis. 2007; 45(8): 992-8.

PubMed Abstract | Publisher Full Text | Faculty Opinions Recommendation 
9. Khanna S, Pardi DS, Aronson SL, et al:: The epidemiology of communityacquired Clostridium difficile infection: a population-based study. $A m$ Gastroenterol. 2012; 107(1): 89-95.

PubMed Abstract | Publisher Full Text | Free Full Text

10. Ofori E, Ramai D, Dhawan M, et al.: Community-acquired Clostridium difficile: epidemiology, ribotype, risk factors, hospital and intensive care unit outcomes, and current and emerging therapies. J Hosp Infect. 2018; 99(4): 436-42.

PubMed Abstract | Publisher Full Text | Faculty Opinions Recommendation

11. Goorhuis A, Bakker D, Corver J, et al.: Emergence of Clostridium difficile infection due to a new hypervirulent strain, polymerase chain reaction ribotype 078. Clin Infect Dis. 2008; 47(9): 1162-70.

PubMed Abstract | Publisher Full Text

12. Lim SK, Stuart RL, Mackin KE, et al:: Emergence of a ribotype 244 strain of Clostridium difficile associated with severe disease and related to the epidemic ribotype 027 strain. Clin Infect Dis. 2014; 58(12): 1723-30. PubMed Abstract | Publisher Full Text

13. De Almeida MN, Heffernan H, Dervan A, et al:: Severe Clostridium difficile infection in New Zealand associated with an emerging strain, PCR-ribotype 244. N Z Med J. 2013; 126(1380): 9-14. PubMed Abstract

14. Rupnik M, Wilcox MH, Gerding DN: Clostridium difficile infection: new developments in epidemiology and pathogenesis. Nat Rev Microbiol. 2009; 7(7): 526-36.

PubMed Abstract | Publisher Full Text

15. Clee HY, Hsiao HL, Chia CY, et al:: Risk factors and outcomes of Clostridium difficile infection in hospitalized patients. Biomed J. 2019; 42(2): 99-106. PubMed Abstract | Publisher Full Text | Free Full Text | Faculty Opinions Recommendation

16. Thibault A, Miller MA, Gaese C: Risk factors for the development of Clostridium difficile-associated diarrhea during a hospital outbreak. Infect Control Hosp Epidemiol. 1991; 12(6): 345-8. PubMed Abstract | Publisher Full Text

17. Hung YP, Lee JC, Tsai BY, et al.: Risk factors of Clostridium difficile-associated diarrhea in hospitalized adults: Vary by hospitalized duration. J Microbiol Immunol Infect. 2019; S1684-1182(19)30088-X. PubMed Abstract | Publisher Full Text | Faculty Opinions Recommendation

18. Dharbhamulla N, Abdelhady A, Domadia M, et al.: Risk Factors Associated With Recurrent Clostridium difficile Infection. J Clin Med Res. 2019; 11(1): 1-6. PubMed Abstract | Publisher Full Text | Free Full Text |

Faculty Opinions Recommendation

19. Paudel S, Zacharioudakis IM, Zervou FN, et al.: Prevalence of Clostridium difficile infection among solid organ transplant recipients: a meta-analysis of published studies. PLoS One. 2015; 10(4): e0124483. PubMed Abstract | Publisher Full Text | Free Full Text

20. Phatharacharukul P, Thongprayoon C, Cheungpasitporn W, et al.: The Risks of Incident and Recurrent Clostridium difficile-Associated Diarrhea in Chronic Kidney Disease and End-Stage Kidney Disease Patients: A Systematic Review and Meta-Analysis. Dig Dis Sci. 2015; 60(10): 2913-22. PubMed Abstract | Publisher Full Text

21. Thongprayoon $\mathrm{C}$, Cheungpasitporn $\mathrm{W}$, Phatharacharukul $\mathrm{P}$, et al:: Chronic kidney disease and end-stage renal disease are risk factors for poor outcomes of Clostridium difficile infection: a systematic review and meta-analysis. Int J Clin Pract. 2015; 69(9): 998-1006.

PubMed Abstract | Publisher Full Text | Free Full Text

22. Shakov R, Salazar RS, Kagunye SK, et al.: Diabetes mellitus as a risk factor for recurrence of Clostridium difficile infection in the acute care hospital setting. Am J Infect Control. 2011; 39(3): 194-8. PubMed Abstract | Publisher Full Text

23. Janarthanan S, Ditah I, Adler DG, et al:: Clostridium difficile-associated diarrhea and proton pump inhibitor therapy: a meta-analysis. $A m \mathrm{~J}$ Gastroenterol. 2012; 107(7): 1001-10.

PubMed Abstract | Publisher Full Text | Faculty Opinions Recommendation

24. Aseeri M, Schroeder T, Kramer J, et al:: Gastric acid suppression by proton pump inhibitors as a risk factor for clostridium difficile-associated diarrhea in hospitalized patients. Am J Gastroenterol. 2008; 103(9): 2308-13. PubMed Abstract

25. Alasmari F, Seiler SM, Hink T, et al:: Prevalence and risk factors for asymptomatic Clostridium difficile carriage. Clin Infect Dis. 2014; 59(2): 216-22 PubMed Abstract | Publisher Full Text | Free Full Text | Faculty Opinions Recommendation

26. Kwon JH, Reske KA, Hink T, et al.: Evaluation of Correlation between Pretest Probability for Clostridium difficile Infection and Clostridium difficile Enzyme Immunoassay Results. J Clin Microbiol. 2017; 55(2): 596-605. PubMed Abstract | Publisher Full Text | Free Full Text

27. Dubberke ER, Han Z, Bobo L, et al.: Impact of clinical symptoms on interpretation of diagnostic assays for Clostridium difficile infections. J Clin Microbiol. 2011; 49(8): 2887-93.

PubMed Abstract | Publisher Full Text | Free Full Text
28. Buckel WR, Avdic E, Carroll KC, et al:: Gut check: Clostridium difficile testing and treatment in the molecular testing era. Infect Control Hosp Epidemiol. 2015 36(2): 217-21.

PubMed Abstract | Publisher Full Text

29. Kirkpatrick IDC, Greenberg HM: Evaluating the CT diagnosis of Clostridium difficile colitis: should CT guide therapy? AJR Am J Roentgenol. 2001; 176(3) 635-9.

PubMed Abstract | Publisher Full Text

30. Burkart NE, Kwaan MR, Shepela C, et al:: Indications and Relative Utility of Lower Endoscopy in the Management of Clostridium difficile Infection. Gastroenterol Res Pract. 2011; 2011: 626582.

PubMed Abstract | Publisher Full Text | Free Full Text

31. Vogelzang EH, Lankelma JM, van Mansfeld R, et al.: Implementing a Clostridium difficile testing algorithm and its effect on isolation duration and treatment initiation: A pre- and post-implementation study. Eur J Clin Microbiol Infect Dis. 2020; 39(6): 1071-6.

PubMed Abstract | Publisher Full Text | Free Full Text | Faculty Opinions Recommendation

32. Planche T, Aghaizu A, Holliman R, et al.: Diagnosis of Clostridium difficile infection by toxin detection kits: A systematic review. Lancet Infect Dis. 2008; 8(12): 777-84.

PubMed Abstract | Publisher Full Text | Faculty Opinions Recommendation

33. Humphries RM, Uslan DZ, Rubin Z: Performance of Clostridium difficile Toxin Enzyme Immunoassay and Nucleic Acid Amplification Tests Stratified by Patient Disease Severity. J Clin Microbiol. 2013; 51(3): 869-73.

PubMed Abstract | Publisher Full Text | Free Full Text |

Faculty Opinions Recommendation

34. Kaltsas A, Simon M, Unruh LH, et al.: Clinical and Laboratory Characteristics of Clostridium difficile Infection in Patients with Discordan Diagnostic Test Results. J Clin Microbiol. 2012; 50(4): 1303-7. PubMed Abstract | Publisher Full Text | Free Full Text | Faculty Opinions Recommendation

35. Fang FC, Polage CR, Wilcox MH, et al.: Point-Counterpoint: What Is the Optimal Approach for Detection of Clostridium difficile Infection? J Clin Microbiol. 2017; 55(3): 670-80

PubMed Abstract | Publisher Full Text | Free Full Text

36. Larson AM, Fung AM, Fang FC: Evaluation of $t c d B$ Real-Time PCR in a Three-Step Diagnostic Algorithm for Detection of Toxigenic Clostridium difficile. J Clin Microbiol. 2010; 48(1): 124-30.

PubMed Abstract | Publisher Full Text | Free Full Text

37. Crobach MJT, Planche T, Eckert C, et al:: European Society of Clinical Microbiology and Infectious Diseases: Update of the diagnostic guidance document for Clostridium difficile infection. Clin Microbiol Infect. 2016; 22 Suppl 4: S63-S81.

PubMed Abstract | Publisher Full Text

38. Longtin Y, Trottier S, Brochu G, et al.: Impact of the type of diagnostic assay on Clostridium difficile infection and complication rates in a mandatory reporting program. Clin Infect Dis. 2013; 56(1): 67-73.

PubMed Abstract | Publisher Full Text | Faculty Opinions Recommendation

39. Polage CR, Gyorke CE, Kennedy MA, et al.: Overdiagnosis of Clostridium difficile Infection in the Molecular Test Era. JAMA Intern Med. 2015; 175(11): 1792-801.

PubMed Abstract | Publisher Full Text | Free Full Text | Faculty Opinions Recommendation

40. Ignatius R, Neuber R, Kietzmann H, et al:: Clostridioides difficile in Outpatients: Application of a Diagnostic Algorithm Recommended by the European Society of Clinical Microbiology and Infectious Diseases. Eur J Microbiol Immunol (Bp). 2019; 9(3): 88-90.

PubMed Abstract | Publisher Full Text | Free Full Text |

Faculty Opinions Recommendation

41. Boone JH, DiPersio JR, Tan MJ, et al.: Elevated lactoferrin is associated with moderate to severe Clostridium difficile disease, stool toxin, and 027 infection. Eur J Clin Microbiol Infect Dis. 2013; 32(12): 1517-23. PubMed Abstract | Publisher Full Text | Free Full Text

42. $\mathrm{He}$ T, Kaplan SE, Gomez LA, et al:: Fecal calprotectin concentrations in cancer patients with Clostridium difficile infection. Eur J Clin Microbiol Infect Dis. 2018; 37(12): 2341-6. PubMed Abstract | Publisher Full Text | Free Full Text | Faculty Opinions Recommendation

43. Whitehead SJ, Shipman KE, Cooper M, et al.: Is there any value in measuring faecal calprotectin in Clostridium difficile positive faecal samples? J Med Microbiol. 2014; 63(Pt 4): 590-3

PubMed Abstract | Publisher Full Text

44. Barbut F, Gouot $\mathrm{C}$, Lapidus N, et al:: Faecal lactoferrin and calprotectin in patients with Clostridium difficile infection: A case-control study. Eur J Clin Microbiol Infect Dis. 2017; 36(12): 2423-30.

PubMed Abstract | Publisher Full Text

45. Aichinger E, Schleck CD, Harmsen WS, et al.: Nonutility of repeat laboratory 
testing for detection of Clostridium difficile by use of PCR or enzyme immunoassay. J Clin Microbiol. 2008; 46(11): 3795-7. PubMed Abstract | Publisher Full Text | Free Full Text

46. Abujamel T, Cadnum JL, Jury LA, et al:: Defining the vulnerable period fo re-establishment of Clostridium difficile colonization after treatment of C. difficile infection with oral vancomycin or metronidazole. PLOS One. 2013 8(10): e76269.

PubMed Abstract | Publisher Full Text | Free Full Text

47. Al-Nassir WN, Sethi AK, Li Y, et al:: Both oral metronidazole and oral vancomycin promote persistent overgrowth of vancomycin-resistant enterococci during treatment of Clostridium difficile-associated disease. Antimicrob Agents Chemother. 2008; 52(7): 2403-6.

PubMed Abstract | Publisher Full Text | Free Full Text

48. Sunkesula VCK, Kundrapu S, Muganda C, et al.: Does empirical Clostridium difficile infection (CDI) therapy result in false-negative CDI diagnostic tes results? Clin Infect Dis. 2013; 57(4): 494-500. PubMed Abstract | Publisher Full Text

49. Koo HL, Koo DC, Musher DM, et al: Antimotility agents for the treatment of Clostridium difficile diarrhea and colitis. Clin Infect Dis. 2009; 48(5): 598-605. PubMed Abstract | Publisher Full Text | Faculty Opinions Recommendation

50. Johnson S, Louie TJ, Gerding DN, et al.: Vancomycin, metronidazole, or tolevamer for Clostridium difficile infection: Results from two multinational, randomized, controlled trials. Clin Infect Dis. 2014; 59(3): 345-54. PubMed Abstract | Publisher Full Text | Faculty Opinions Recommendation

51. Zar FA, Bakkanagari SR, Moorthi KMLST, et al: A comparison of vancomycin and metronidazole for the treatment of Clostridium difficile-associated diarrhea, stratified by disease severity. Clin Infect Dis. 2007; 45(3): 302-7.

PubMed Abstract | Publisher Full Text | Faculty Opinions Recommendation

52. Siegfried J, Dubrovskaya Y, Flagiello T, et al:: Initial Therapy for Mild to Moderate Clostridium difficile Infection. Infect Dis Clin Prac. 2016; 24(4): 210-6. Publisher Full Text

53. Wilcox MH, Howe R: Diarrhoea caused by Clostridium difficile: Response time for treatment with metronidazole and vancomycin. J Antimicrob Chemother. 1995; 36(4): 673-9

PubMed Abstract | Publisher Full Text

54. Yamamoto T, Abe K, Anjiki H, et al:: Metronidazole-Induced Neurotoxicity Developed in Liver Cirrhosis. J Clin Med Res. 2012; 4(4): 295-8. PubMed Abstract | Publisher Full Text | Free Full Text

55. Knorr JP, Javed I, Sahni N, et al.: Metronidazole-Induced Encephalopathy in a Patient with End-Stage Liver Disease. Case Reports Hepatol. 2012; 2012 209258.

PubMed Abstract | Publisher Full Text | Free Full Text

56. Cornely OA, Crook DW, Esposito R, et al:: Fidaxomicin versus vancomycin for infection with Clostridium difficile in Europe, Canada, and the USA: A double-blind, non-inferiority, randomised controlled trial. Lancet Infect Dis. 2012; 12(4): 281-9.

PubMed Abstract | Publisher Full Text | Faculty Opinions Recommendation

57. Louie TJ, Miller MA, Mullane KM, et al.: Fidaxomicin versus Vancomycin for Clostridium difficile Infection. N Engl J Med. 2011; 364(5): 422-31. PubMed Abstract | Publisher Full Text | Faculty Opinions Recommendation

58. Musher DM, Logan N, Bressler AM, et al.: Nitazoxanide versus Vancomycin in Clostridium difficile Infection: A Randomized, Double-Blind Study. Clin Infect Dis. 2009; 48(4): e41-e46.

PubMed Abstract | Publisher Full Text

59. Vickers RJ, Tillotson GS, Nathan R, et al.: Efficacy and safety of ridinilazole compared with vancomycin for the treatment of Clostridium difficile infection A phase 2, randomised, double-blind, active-controlled, non-inferiority study. Lancet Infect Dis. 2017; 17(7): 735-44.

PubMed Abstract | Publisher Full Text | Free Full Text

60. Wullt M, Odenholt I: A double-blind randomized controlled trial of fusidic acid and metronidazole for treatment of an initial episode of Clostridium difficile-associated diarrhoea. J Antimicrob Chemother. 2004; 54(1): 211-6. PubMed Abstract | Publisher Full Text

61. Garey KW, Ghantoji SS, Shah DN, et al:: A randomized, double-blind, placebo-controlled pilot study to assess the ability of rifaximin to preven recurrent diarrhoea in patients with Clostridium difficile infection. $J$ Antimicrob Chemother. 2011; 66(12): 2850-5.

PubMed Abstract | Publisher Full Text | Faculty Opinions Recommendation

62. Mattila E, Arkkila P, Mattila PS, et al.: Rifaximin in the treatment of recurrent Clostridium difficile infection. Aliment Pharmacol Ther. 2013; 37(1): 122-8. PubMed Abstract | Publisher Full Text

63. Lagrotteria D, Holmes S, Smieja M, et al.: Prospective, Randomized Inpatient Study of Oral Metronidazole versus Oral Metronidazole and Rifampin for Treatment of Primary Episode of Clostridium difficile-Associated Diarrhea. Clin Infect Dis. 2006; 43(5): 547-52.

PubMed Abstract | Publisher Full Text

64. Gergely Szabo B, Kadar B, Szidonia Lenart K, et al:: Use of intravenous tigecycline in patients with severe Clostridium difficile infection: A retrospective observational cohort study. Clin Microbiol Infect. 2016; 22(12):
$990-5$.

PubMed Abstract | Publisher Full Text

65. Wenisch C, Parschalk B, Hasenhündl $M$, et al: Comparison of Vancomycin Teicoplanin, Metronidazole, and Fusidic Acid for the Treatment of Clostridium difficile-Associated Diarrhea. Clin Infect Dis. 1996; 22(5): 813-8. PubMed Abstract | Publisher Full Text

66. Louie T, Nord CE, Talbot GH, et al:: Multicenter, Double-Blind, Randomized, Phase 2 Study Evaluating the Novel Antibiotic Cadazolid in Patients with Clostridium difficile Infection. Antimicrob Agents Chemother. 2015; 59(10): 6266-73

PubMed Abstract | Publisher Full Text | Free Full Text

67. Daley $\mathrm{P}$, Louie T, Lutz JE, et al: Surotomycin versus vancomycin in adults with Clostridium difficile infection: Primary clinical outcomes from the second pivotal, randomized, double-blind, Phase 3 trial. J Antimicrob Chemother. 2017; 72(12): 3462-70.

PubMed Abstract | Publisher Full Text

68. Pépin J, Valiquette L, Gagnon S, et al:: Outcomes of Clostridium difficile-Associated Disease Treated With Metronidazole or Vancomycin Before and After the Emergence of NAP1/027. Am J Gastroenterol. 2007; 102(12): 2781-8.

PubMed Abstract

69. Olsen MA, Yan Y, Reske KA, et al:: Recurrent Clostridium difficile infection is associated with increased mortality. Clin Microbiol Infect. 2015; 21(2): 164-70. PubMed Abstract | Publisher Full Text

70. Sim JHC, Truong C, Minot SS, et al:: Determining the cause of recurrent Clostridium difficile infection using whole genome sequencing. Diagn Microbio Infect Dis. 2017; 87(1): 11-6.

PubMed Abstract | Publisher Full Text

71. Do AN, Fridkin SK, Yechouron A, et al:: Risk Factors for Early Recurrent Clostridium difficile-Associated Diarrhea. Clin Infect Dis. 1998; 26(4): 954-9. PubMed Abstract | Publisher Full Text

72. Tariq R, Singh S, Gupta A, et al:: Association of Gastric Acid Suppression With Recurrent Clostridium difficile Infection: A Systematic Review and Meta-analysis. JAMA Intern Med. 2017; 177(6): 784-91. PubMed Abstract | Publisher Full Text | Free Full Text

73. Sirbu BD, Soriano MM, Manzo C, et al:: Vancomycin Taper and Pulse Regimen With Careful Follow-up for Patients With Recurrent Clostridium difficile Infection. Clin Infect Dis. 2017; 65(8): 1396-9. PubMed Abstract | Publisher Full Text

74. Spiceland CM, Khanna S, Pardi DS: Outcomes With Fidaxomicin Therapy in Clostridium difficile Infection. J Clin Gastroenterol. 2018; 52(2): 151-4. PubMed Abstract | Publisher Full Text | Faculty Opinions Recommendation

75. Cornely OA, Miller MA, Louie TJ, et al:: Treatment of first recurrence of Clostridium difficile infection: fidaxomicin versus vancomycin. Clin Infect Dis. 2012; 55 Suppl 2(Suppl 2): S154-61. PubMed Abstract | Publisher Full Text | Free Full Text | Faculty Opinions Recommendation

76. Major G, Bradshaw L, Boota N, et al.: Follow-on RifAximin for the Prevention of recurrence following standard treatment of Infection with Clostridium Difficile (RAPID): a randomised placebo controlled trial. Gut. 2019; 68(7): 1224-31.

PubMed Abstract | Free Full Text | Faculty Opinions Recommendation

77. Hvas CL, Dahl Jørgensen SM, Jørgensen SP, et al.: Fecal Microbiota Transplantation Is Superior to Fidaxomicin for Treatment of Recurrent Clostridium difficile Infection. Gastroenterology. 2019; 156(5): 1324-1332.e3. PubMed Abstract | Publisher Full Text | Faculty Opinions Recommendation

78. Peng Z, Ling L, Stratton CW, et al:: Advances in the diagnosis and treatment of Clostridium difficile infections. Emerg Microbes Infect. 2018; 7: 15. PubMed Abstract | Publisher Full Text | Free Full Text |

Faculty Opinions Recommendation

79. Leffler DA, Lamont JT: Clostridium difficile infection. N Engl J Med. 2015; 372(16): 1539-48

PubMed Abstract | Publisher Full Text

80. Youngster I, Mahabamunuge J, Systrom HK, et al.: Oral, frozen fecal microbiota transplant (FMT) capsules for recurrent Clostridium difficile infection. BMC Med. 2016; 14(1): 134. infection. BMC Med. 2016; 14(1): 134.
PubMed Abstract | Publisher Full Text | Free Full Text | Faculty Opinions Recommendation

81. Wang JW, Kuo CH, Kuo FC, et al.: Fecal microbiota transplantation: Review and update. J Formos Med Assoc. 2019; 118 Suppl 1: S23-S31. PubMed Abstract | Publisher Full Text | Faculty Opinions Recommendation

82. Juul FE, Garborg K, Bretthauer M, et al.: Fecal Microbiota Transplantation for Primary Clostridium difficile Infection. N Engl J Med. 2018; 378(26): 2535-6. PubMed Abstract | Publisher Full Text | Faculty Opinions Recommendation

83. Qazi T, Amaratunga T, Barnes EL, et al.: The risk of inflammatory bowel disease flares after fecal microbiota transplantation: Systematic review and meta-analysis. Gut Microbes. 2017; 8(6): 574-88. PubMed Abstract | Publisher Full Text | Free Full Text

84. Khanna S, Vazquez-Baeza Y, González A, et al.: Changes in microbial ecology 
after fecal microbiota transplantation for recurrent $C$. difficile infection affected by underlying inflammatory bowel disease. Microbiome. 2017; 5(1): 55. PubMed Abstract | Publisher Full Text | Free Full Text

85. Fischer M, Kao D, Kelly C, et al:: Fecal Microbiota Transplantation is Safe and Efficacious for Recurrent or Refractory Clostridium difficile Infection in Patients with Inflammatory Bowel Disease. Inflamm Bowel Dis. 2016; 22(10): 2402-9.

PubMed Abstract | Publisher Full Text | Faculty Opinions Recommendation

86. DeFilipp Z, Bloom PP, Soto MT, et al.: Drug-Resistant E. coli Bacteremia Transmitted by Fecal Microbiota Transplant. N Engl J Med. 2019; 381(21): 2043-50.

PubMed Abstract | Publisher Full Text | Faculty Opinions Recommendation

87. Jorup-Rönström C, Håkanson A, Sandell S, et al.: Fecal transplant against relapsing Clostridium difficile-associated diarrhea in 32 patients. Scand J Gastroenterol. 2012; 47(5): 548-52.

PubMed Abstract | Publisher Full Tex

88. Tang G, Yin W, Liu W: Is frozen fecal microbiota transplantation as effective as fresh fecal microbiota transplantation in patients with recurrent or refractory Clostridium difficile infection: A meta-analysis? Diagn Microbiol Infect Dis. 2017 ; 88(4): 322-9.

PubMed Abstract | Publisher Full Text

89. Jiang ZD, Ajami NJ, Petrosino JF, et al:: Randomised clinical trial: faecal microbiota transplantation for recurrent Clostridum difficile infection - fresh, or frozen, or lyophilised microbiota from a small pool of healthy donors delivered by colonoscopy. Aliment Pharmacol Ther. 2017; 45(7): 899-908. PubMed Abstract | Publisher Full Text

90. Brandt LJ, Aroniadis OC, Mellow M, et al: Long-term follow-up of colonoscopic fecal microbiota transplant for recurrent Clostridium difficile infection. Am J Gastroenterol. 2012; 107(7): 1079-87.

PubMed Abstract | Publisher Full Text

91. Rokas KEE, Johnson JW, Beardsley JR, et al.: The Addition of Intravenous Metronidazole to Oral Vancomycin is Associated With Improved Mortality in Critically III Patients With Clostridium difficile Infection. Clin Infect Dis. 2015; 61(6): 934-41.

PubMed Abstract | Publisher Full Text

92. Friedenberg F, Fernandez A, Kaul V, et al: Intravenous metronidazole for the treatment of Clostridium difficile colitis. Dis Colon Rectum. 2001; 44(8): 1176-80.

PubMed Abstract | Publisher Full Text

93. Matzke GR, Halstenson CE, Olson PL, et al:: Systemic absorption of oral vancomycin in patients with renal insufficiency and antibiotic-associated colitis. Am J Kidney Dis. 1987; 9(5): 422-5. PubMed Abstract | Publisher Full Text

94. Hocquart M, Lagier JC, Cassir N, et al.: Early Fecal Microbiota Transplantation Improves Survival in Severe Clostridium difficile Infections. Clin Infect Dis.. 2018; 66(5): 645-50.

PubMed Abstract | Publisher Full Text | Faculty Opinions Recommendation

95. Abou Khalil M, Bhatnagar SR, Feldman L, et al.: Development and validation of a clinical risk calculator for mortality after colectomy for fulminant Clostridium difficile colitis. J Trauma Acute Care Surg. 2019; 87(4): 856-64. PubMed Abstract | Publisher Full Text | Faculty Opinions Recommendation

96. Lamontagne $F$, Labbé AC, Haeck $O$, et al:: Impact of emergency colectomy on survival of patients with fulminant Clostridium difficile colitis during an epidemic caused by a hypervirulent strain. Ann Surg. 2007; 245(2): 267-72. PubMed Abstract | Publisher Full Text | Free Full Text

97. Sailhamer EA, Carson $\mathrm{K}$, Chang $\mathrm{Y}$, et al: Fulminant Clostridium difficile colitis: patterns of care and predictors of mortality. Arch Surg. 2009; 144(5): 433-9; discussion 439-40.

PubMed Abstract | Publisher Full Text

98. McDonald LC: Clostridium difficile: responding to a new threat from an old enemy. Infect Control Hosp Epidemiol. 2005; 26(8): 672-5. PubMed Abstract | Publisher Full Text

99. Ali SO, Welch JP, Dring RJ: Early surgical intervention for fulminant pseudomembranous colitis. Am Surg. 2008; 74(1): 20-6. PubMed Abstract | Publisher Full Text

100. Bhangu A, Nepogodiev D, Gupta A, et al:: Systematic review and meta-analysis of outcomes following emergency surgery for Clostridium difficile colitis. Br J Surg. 2012; 99(11): 1501-13. PubMed Abstract | Publisher Full Text | Faculty Opinions Recommendation

101. Wilcox MH, Gerding DN, Poxton IR, et al.: Bezlotoxumab for Prevention of Recurrent Clostridium difficile Infection. N Engl J Med. 2017; 376(4): 305-17. PubMed Abstract | Publisher Full Text | Faculty Opinions Recommendation

102. Alonso CD, Mahoney MV: Bezlotoxumab for the prevention of Clostridium difficile infection: a review of current evidence and safety profile. Infect Drug
Resist. 2019; 12: 1-9.

PubMed Abstract | Publisher Full Text | Free Full Text |

Faculty Opinions Recommendation

103. Merck \& Co Inc: Zinplava (bezlotoxumab) [package insert]. Merck \& Co, Inc: Whitehouse Station, NJ, 2016.

104. Gerding DN, Kelly CP, Rahav G, et al.: Bezlotoxumab for Prevention of Recurrent Clostridium difficile Infection in Patients at Increased Risk for Recurrence. Clin Infect Dis. 2018; 67(5): 649-56. PubMed Abstract | Publisher Full Text | Free Full Text | Faculty Opinions Recommendation

105. Basu A, Prabhu VS, Dorr MB, et al.: Bezlotoxumab Is Associated With a Reduction in Cumulative Inpatient-Days: Analysis of the Hospitalization Data From the MODIFY I and II Clinical Trials. Open Forum Infect Dis. 2018; 5(11): ofy218.

PubMed Abstract | Publisher Full Text | Free Full Text | Faculty Opinions Recommendation

106. Hengel RL, Ritter TE, Nathan RV, et al.: Real-world Experience of Bezlotoxumab for Prevention of Clostridioides difficile Infection: A Retrospective Multicenter Cohort Study. Open Forum Infect Dis. 2020; 7(4): ofaa097.

PubMed Abstract | Publisher Full Text | Free Full Text |

Faculty Opinions Recommendation

107. Dubberke ER, Schaefer E, Reske KA, et al.: Attributable Inpatient Costs of Recurrent Clostridium difficile Infections. Infect Control Hosp Epidemiol. 2014; 35(11): 1400-7. PubMed Abstract | Publisher Full Text

108. Nuijten MJ, Keller JJ, Visser CE, et al.: Cost-effectiveness in Clostridium difficile treatment decision-making. World J Clin Cases. 2015; 3(11): 935-41. PubMed Abstract | Publisher Full Text | Free Full Text

109. Rathish B, Wilson A, Warrier A, et al:: How to Save Half a Million Dollars: An Antimicrobial Stewardship Program in a Tertiary Care Center. Cureus. 2019; 11(7): e5121.

PubMed Abstract | Publisher Full Text | Free Full Text | Faculty Opinions Recommendation

110. Ford DC, Schroeder MC, Ince D, et al:: Cost-effectiveness analysis of initial treatment strategies for mild-to-moderate Clostridium difficile infection in hospitalized patients. Am J Health Syst Pharm. 2018; 75(15): 1110-21. PubMed Abstract | Publisher Full Text | Faculty Opinions Recommendation

111. Stranges PM, Hutton DW, Collins CD: Cost-Effectiveness Analysis Evaluating Fidaxomicin versus Oral Vancomycin for the Treatment of Clostridium difficile Infection in the United States. Value in Health. 2013; 16(2): 297-304. PubMed Abstract | Publisher Full Text

112. Le P, van Nghiem T, Mullen PD, et al:: Cost-Effectiveness of Competing Treatment Strategies for Clostridium difficile Infection: A Systematic Review. Infect Control Hosp Epidemiol. 2018; 39(4): 412-24. PubMed Abstract | Publisher Full Text | Free Full Text | Faculty Opinions Recommendation

113. Rajasingham R, Enns EA, Khoruts A, et al.: Cost-effectiveness of Treatment Regimens for Clostridioides difficile Infection: An Evaluation of the 2018 Infectious Diseases Society of America Guidelines. Clin Infect Dis. 2020; 70(5): 754-62.

PubMed Abstract | Publisher Full Text | Free Full Text |

Faculty Opinions Recommendation

114. Nathwani D, Cornely OA, van Engen AK, et al.: Cost-effectiveness analysis of fidaxomicin versus vancomycin in Clostridium difficile infection. $J$ Antimicrob Chemother. 2014; 69(11): 2901-12.

PubMed Abstract | Publisher Full Text | Free Full Text

115. Konijeti GG, Sauk J, Shrime MG, et al.: Cost-effectiveness of Competing Strategies for Management of Recurrent Clostridium difficile Infection: A Decision Analysis. Clin Infect Dis. 2014; 58(11): 1507-14. PubMed Abstract | Publisher Full Text | Free Full Text

116. Arbel LT, Hsu E, McNally K: Cost-Effectiveness of Fecal Microbiota Transplantation in the Treatment of Recurrent Clostridium Difficile Infection: A Literature Review. Cureus. 2017; 9(8): e1599.

PubMed Abstract | Publisher Full Text | Free Full Text

117. Burton HE, Mitchell SA, Watt M: A Systematic Literature Review of Economic Evaluations of Antibiotic Treatments for Clostridium difficile Infection. Pharmacoeconomics. 2017; 35(11): 1123-40. PubMed Abstract | Publisher Full Text | Free Full Text

118. Shen NT, Maw A, Tmanova LL, et al:: Timely Use of Probiotics in Hospitalized Adults Prevents Clostridium difficile Infection: A Systematic Review With Meta-Regression Analysis. Gastroenterology. 2017; 152(8): 1889-1900.e9. PubMed Abstract | Publisher Full Text | Faculty Opinions Recommendation 